UDC 342.534.1(094.5)

Dr Bosa Nenadić

sudija Ustavnog suda Srbije

\title{
O NESAGLASNOSTI SA USTAVOM ODREDBE ČLANA 88. STAV 1. TAČ. 1) I 9) ZAKONA O IZBORU NARODNIH POSLANIKA*1
}

Ustavni sud Republike Srbije je na sednici održanoj 23. oktobra 2002. godine, po sopstvenoj inicijativi, pokrenuo postupak za ocenu ustavnosti odredaba člana 88. stav 1. tač. 1) i 9) Zakona o izboru narodnih poslanika (,Službeni glasnik RS”, broj 35/2000).

U Rešenju o pokretanju postupka za ocenu ustavnosti odredaba člana 88. stav 1. tač. 1) i 9) Zakona o izboru narodnih poslanika ${ }^{2}$ Ustavni sud je, između ostalog, postavio sledeća ustavno-pravna pitanja:

- da li se zakonodavac, uređujući prestanak mandata narodnih poslanika pre vremena na koje su izabrani, u osporenim odredbama Zakona kretao u okviru ustavnih načela i principa utvrđenih u odredbama čl. 2, 42, 44, 74. i 76. Ustava Republike Srbije;

- da li osporene odredbe Zakona ograničavaju slobodu poslanika u vršenju poslaničke funkcije i posredno uvode imperativni mandat poslanika u odnosu na političku stranku ili drugu političku organizaciju koja ga je kandidovala;

- da li zakonom utvrđeni tip (model) izbornog sistema opredeljuje prirodu i karakter mandata narodnih poslanika, ili je on opredeljen Ustavom;

* Rad primljen: 27. V 2003.

1 Ovaj tekst predstavlja referat dr Bose Nenadić, sudije izvestioca, na sednici Ustavnog suda Srbije od 27. maja 2003. godine, o većanju i glasanju o ustavnosti odredaba člana 88. stav l. tač. I) i 9) Zakona o izboru narodnih poslanika (,Službeni glasnik RS”, broj $35 / 2000$ ).

2 Vid. Rešenje o pokretanju postupka za ocenu ustavnosti odredaba člana 88. stav 1. tač. 1) i 9) Zakona o izboru narodnih poslanika (,,Službeni glasnik RS”, broj 69/02). 
- da li osnovi za prestanak mandata narodnih poslanika, onako kako su utvrđeni u osporenim odredbama Zakona, dovode u pitanje Ustavom utvrđeno svojstvo narodnih poslanika kao predstavnika građana;

- da li je u saglasnosti s Ustavom osporena odredba Zakona po kojoj brisanje političke stranke, odnosno druge političke organizacije iz registra kod nadležnog organa, nezavisno od razloga brisanja, ima za posledicu prestanak mandata poslanika izabranih sa liste te stranke, odnosno druge političke organizacije.

Nakon pokretanja postupka za ocenu ustavnosti navedenih odredaba člana 88. stav 1. tač 1) i 9) Zakona o izboru narodnih poslanika od strane Ustavnog suda Republike Srbije, Sudu su podneti i predlozi Fonda za razvoj demokratije iz Beograda i Stranke srbskog prosperiteta i Ujedinjene penzionerske stranke Srbije za utvrđivanje neustavnosti osporenih odredaba Zakona.

\section{II}

Rešenje Ustavnog suda o pokretanju postupka za ocenu ustavnosti odredaba člana 88. stav 1. tač. 1) i 9), saglasno članu 64. Zakona o postupku pred Ustavnim sudom i pravnom dejstvu njegovih odluka („Službeni glasnik RS", br. 32/91. i 67/93) dostavljeno je Narodnoj skupštini Republike Srbije na odgovor. U odgovoru Zakonodavnog odbora Narodne skupštine od 26. oktobra 2002. godine ističe se:

- da se ,izbori za narodne poslanike... organizuju po proporcionalnom sistemu, što znači da se kandidati za narodne poslanike kandiduju na stranačkim ili koalicionim listama, što je u skladu sa članom 42. stav 3. Ustava”. Glasanjem se birači „opredeljuju za liste i političke programe stranaka, odnosno koalicija tako da je sam ustavotvorac i zakonodavac ustanovio vezu između poslanika, birača i političkih stranaka";

- da isključenje iz stranke, odnosno koalicije predstavlja jedan od osnova koje je zakonodavac propisao za prestanak poslaničkog mandata, jer je zakonodavac takođe predvideo kao jedan od uslova za sticanje te poslaničke funkcije upravo kandidovanje na listi političke stranke, odnosno koalicije, a odredba člana 76. Ustava se „odnosi na period u kome jedno lice obavlja funkciju narodnog poslanika";

- da osporene odredbe Zakona ne sužavaju, niti ograničavaju Ustavom utvrđeni položaj narodnog poslanika i njegovo pravo da odlučuje i glasa po sopstvenom uverenju. To pravo bilo bi ograničeno „kada bi glasanje, odnosno odlučivanje po sopstvenom uverenju bilo osnov za prestanak mandata";

- da u Zakonu o izboru narodnih poslanika nije predviđen institut opoziva, nego su normirani razlozi za prestanak mandata narodnih poslanika, s tim što je ,sam ustavotvorac u članu 74. stav 3. Ustava regulisao da se izbori i prestanak mandata narodnih poslanika uređuje zakonom". 
Osporene odredbe člana 88. stav 1. tač. 1) i 9) Zakona o izboru narodnih poslanika glase:

„Poslaniku prestaje mandat pre isteka vremena na koje je izabran:

1) ako mu prestane članstvo u političkoj stranci ili koaliciji na čijoj izbornoj listi je izabran za poslanika,

9) brisanjem iz registra kod nadležnog organa političke stranke, odnosno druge političke organizacije na čijoj izbornoj listi je izabran."

Stavom 2. člana 88. Zakona o izboru narodnih poslanika predviđeno je da poslaniku mandat prestaje danom nastupanja slučaja iz stava 1 . ovog člana. Prema stavu 3. tog člana dan prestanka mandata konstatuje Narodna skupština Republike Srbije na prvoj narednoj sednici posle prijema obaveštenja o razlozima za prestanak mandata.

U sagledavanju ustavnopravne zasnovanosti rešenja iz člana 88. stav 1. tač. 1) i 9) Zakona, po našem mišljenju, treba imati u vidu sledeće odredbe Ustava Republike Srbije:

- član 2. Ustava, po kome suverenost u Republici Srbiji pripada svim građanima Republike, a suverenost građani ostvaruju referendumom, narodnom inicijativom i preko svojih izabranih predstavnika;

- član 13. Ustava, koji jamči jednakost građana u pravima i dužnostima i jednaku zaštitu pred državnim i drugim organima bez obzira na „...političko ili drugo uverenje, ... ili koje lično svojstvo";

- član 42. Ustava, u kome je utvrđeno da građanin koji je navršio 18 godina života ima pravo da bira i da bude biran u Narodnu skupštinu i u druge organe i izborna tela (stav 1), i da su izbori neposredni, biračko pravo opšte i jednako, a glasanje tajno (stav 2). U stavu 3. člana 42. Ustava predviđeno je da kandidata za narodnog poslanika i za druge organe i izborna tela može predložiti politička stranka, druga politička organizacija ili grupa građana;

- član 44. stav 1. Ustava koji garantuje slobodu političkog, sindikalnog i drugog organizovanja i delovanja (i bez odobrenja uz upis u registar kod nadležnog organa), osim u slučajevima utvrđenim u stavu 2. tog člana;

- član 74. stav 2. Ustava, saglasno kome narodne poslanike građani biraju na neposrednim izborima, tajnim glasanjem, i stav 3. ovog člana po kome se izbor i prestanak mandata narodnih poslanika uređuje zakonom;

- član 75. stav 1. Ustava po kome se narodni poslanici biraju na četiri godine,$^{3} \mathrm{i}$

3 U st. 2. do 4. člana 75. Ustava utvrđeni su i rokovi za izbor narodnih poslanika, verifikacija mandata novih narodnih poslanika, prestanak funkcije poslanika čiji mandat ističe i slučajevi produženja mandata narodnih poslanika. 
- član 76. Ustava u kome je utvrđeno da narodni poslanik predstavlja građane izborne jedinice u kojoj je izabran. ${ }^{4}$

Iz navedenih ustavnih odredbi proizlazi da Ustav Republike Srbije nije utvrdio osnove i razloge za prestanak mandata narodnih poslanika, ${ }^{5}$ već je predvideo da će se prestanak mandata narodnih poslanika urediti zakonom. Ti razlozi i osnovi su utvrđeni članom 88. stav 1 . Zakona o izboru narodnih poslanika. ${ }^{6} \mathrm{~S}$ obzirom da je odredba člana 74. stav 3 . Ustava ovlašćujućeg karaktera, zakonodavac se prilikom uređivanja izbora i prestanka mandata narodnih poslanika mora kretati u okviru i u granicama ustavnih načela i odredbi o parlamentarnom (narodnom, građanskom) predstavništvu, izbornom pravu (aktivnom i pasivnom biračkom pravu), pravu na kandidovanje, neposrednim izborima i mandatu narodnih poslanika. Prema tome, navedene ustavne odredbe predstavljaju granicu do koje i u okviru koje se može kretati zakonodavac u uređivanju izbora i prestanka mandata narodnih poslanika.

\section{IV}

Na sednici održanoj 4. februara 2003. godine Ustavni sud je zaključio da su ustavno-pravna pitanja koja se postavljaju povodom ocene ustavnosti osporenih odredaba Zakona o izboru narodnih poslanika od načelnog i šireg pravnog značaja za ostvarivanje ustavnosti i da se zbog njihovog svestranijeg i potpunijeg sagledavanja održi javna rasprava.

Javna rasprava, uz učešće predstavnika Narodne skupštine Republike Srbije, predstavnika nadležnih republičkih organa, predstavnika podnosilaca predstavki i jednog broja naučnih radnika, održana je 26. februara

${ }^{4}$ Prema članu 4. Zakona o izboru narodnih poslanika, Republika Srbija čini jednu izbornu jedinicu.

5 Po sili Ustava mandat poslanika prestaje pre isteka vremena na koji su izabrani u slučaju raspuštanja Narodne skupštine (član 89. Ustava).

6 Zakonom utvrđeni razlozi bi se mogli svrstati u dve grupe. Jednu grupu čine tzv. standardni razlozi, koje sa neznatnim razlikama poznaju skoro sva savremena evropska zakonodavstva. To su: 1) razlozi vezani za prestanak uslova za sticanje biračkog prava (gubljenje državljanstva, lišenje poslovne sposobnosti, prestanak prebivališta na teritoriji Republike); 2) razlozi vezani za pravne odluke koje utiču na status poslanika (pravosnažna sudska odluka na kaznu zatvora bezuslovno u trajanju od najmanje šest meseci ili preuzimanje funkcije ili posla od strane poslanika koje su nespojive sa funkcijom narodnog poslanika); 3) razlozi lične prirode (ostavka, smrt). Ovi razlozi odnose se na sve poslanike Narodne skupštine. Drugu grupu čine razlozi koje poznaje naše zakonodavstvo (i zakonodavstvo Republike Crne Gore) kao jedno od retkih, ako ne i jedino u Evropi, a to su razlozi vezani za pripadnost poslanika političkoj stranci ili njihovim savezima, a koji su upravo utvrđeni u osporenim odredbama člana 88. Zakona. Ovi razlozi se ne odnose na sve narodne poslanike već samo na one koji su članovi političkih stranaka, odnosno koji su izabrani na stranačkim listama.

Pored navedenih osnova za prestanak mandata, u nekim zemljama postoje i razlozi specifične prirode koji nisu šire prihvaćeni. Npr. u Austriji se poslanički mandat može izgubiti ako poslanik određeno vreme ne prisustvuje sednicama parlamenta ili ne položi zakletvu. 
2003. godine. Na raspravi su razmotrena otvorena ustavno-pravna pitanja koja su bila postavljena u Referatu za Javnu raspravu.

Ustavni sud je takođe, na Pripremnoj sednici Suda održanoj 29. aprila 2003. godine, razmotrio otvorena ustavno-pravna pitanja koja su bila predmet razmatranja na Javnoj raspravi, kao i druga pitanja od značaja za odlučivanje Ustavnog suda u ovoj pravnoj stvari.

\section{V}

Uloga političkih stranaka u izgrađivanju političkog predstavništva danas je nesumnjiva i nesporna, kao i njihov odlučujući uticaj na donošenje političkih odluka u zemlji. Taj položaj ima i svoju pravnu osnovu u odredbama Ustava, a potom i u zakonima i drugim aktima koji uređuju izborne postupke, u zakonima o organizovanju i delovanju političkih stranaka, kao i parlamentarnim poslovnicima. Svojom aktivnošću stranke podstiču građane na korišćenje njihovog izbornog prava i drugih političkih prava. Bez njihove aktivnosti teško bi se danas izbori za narodne poslanike mogli uspešno obaviti. Tako, narodne poslanike (i odbornike), kao i druge nosioce javnih funkcija na svim nivoima organizovanja građani, pre svega, biraju na osnovu izbornih lista i predloga političkih stranaka, opredeljujući se za ovu ili onu stranku polazeći prevashodno od njenog programa, a potom i prema ličnim svojstvima predloženih kandidata. U praksi, narodni poslanici za sticanje poslaničke funkcije pre svega ,duguju svojoj partiji”, pa je samim tim nesporno da će ti poslanici u svom radu u Skupštini biti pod znatnim uticajem svoje političke partije. ${ }^{7}$ Saglasno tome, određeni odnosi i stalne veze političke stranke i člana predstavničkog tela postoje i faktički se ostvaruju. Međutim, pitanje je samo prirode i sadržine odnosa poslanika i političke partije, tj. koliko je taj odnos politički a koliko može biti pravno obavezujući i dokle seže „pravo” stranke da utiče na vršenje poslaničke funkcije.

\section{VI}

U vezi sa ocenom ustavnosti odredbe člana 88. stav 1. tačka 1) Zakona o izboru narodnih poslạnika, po našem mišljenju, treba imati u vidu sledeće:

Ustav Republike Srbije u članu 42. stav 1. garantuje pasivno biračko pravo građanina kao individualno i jedno od osnovnih prava građana koje se ostvaruje na osnovu Ustava. U članu 9. Zakona o izboru narodnih po-

7 Taj uticaj se pre svega ostvaruje kroz poslaničke grupe koje se obrazuju u Narodnoj skupštini. U poslaničkoj grupi se poslanici koji pripadaju istoj partiji dobrovoljno udružuju u cilju prethodnog razmatranja i zauzimanja stavova o pitanjima koja su na dnevnom redu Skupštine ili njenih radnih tela, odnosno u pogledu delovanja i odlučivanja (glasanja) u Skupštini. 
slanika, ovo pravo se definiše kao pravo građana da budu kandidovani i jedno je u nizu prava koja čine sadržinu izbornog prava zagarantovanog Ustavom. Članom 42. stav 3. Ustava utvrđeno je samo da kandidata za narodnog poslanika može predložiti politička stranka, druga politička organizacija ili grupa građana. Pri tome, navedena odredba Ustava dopušta da za kandidata za narodnog poslanika mogu biti predloženi i građani koji nisu članovi političke stranke, a oni su u izbornim procesima u dosadašnjoj praksi i predlagani. Isticanje kandidature na izbornoj listi političke stranke, odnosno listi bilo kog drugog subjekta kandidovanja iz člana 42. stav 3. Ustava nije uslov za sticanje pasivnog biračkog prava, jer su liste samo način ili tehnika ostvarivanja prava na kandidovanje. To pravo Ustav ne zasniva na tipu izbornog sistema. Tip izbornog sistema utiče na način kandidovanja - bolje reći na tehniku kako cee se kandidovanje izvesti, tj. opredeljuje način na koji će neko ko ima pravo kandidovanja ostvariti to svoje pravo. Način kandidovanja, na izbornim listama ili uninominalno, nije uslov za sticanje pasivnog biračkog prava, već pasivno biračko pravo građanin uživa kao subjektivno javno pravo na osnovu samog Ustava. U suprotnom, svaka promena tipa izbornog sistema od strane zakonodavca relativizovala bi Ustavom zagarantovano izborno pravo, što bi bilo suprotno ustavnim načelima i principima utvrđenim u čl. 2 . i 42, članu 72. st. 1. i 2 . i članu 76. Ustava. ${ }^{8}$

Pravo da kandiduje narodne poslanike prema Ustavu i Zakonu o izboru narodnih poslanika dato je političkoj stranci (samostalno ili u koaliciji) ili drugoj političkoj organizaciji i grupi građana. U tom pogledu ni Ustav ni Zakon ne prave nikakvu razliku između predlagača. Uređujući postupak izbora narodnih poslanika Zakon ne govori ni o jednom predlagaču pojedinačno, već o ,predlagačima kandidatskih lista”. Kada utvrđuje pravo na kandidovanje Ustav koristi veoma precizne termine „kandidata za narodnog poslanika može predložiti...". Zakon to isto čini. Osim toga, zakonodavac i u ovoj fazi postupka u prvi plan stavlja pojedinca, odnosno kandidata koji se nalazi na listi. ${ }^{9}$

Prema tome, nesporno je da se pravo kandidovanja konstituiše kao pravo građana, a ne kao pravo članova političkih organizacija, a sadržaj prava na kandidovanje subjekata iz člana 42. stava 3. Ustava tj. političkih stranaka, odnosno drugih političkih organizacija ili grupe građana se iscrpljuje u pravu da slobodno nominuju odnosno predlažu kandidate za poslanika. Postupak kandidovanja je polje slobodnog delovanja političkih stranaka i drugih političkih organizacija i grupa građana, i predstavlja jed-

8 To potvrđuje i uporedno parlamentarno iskustvo Engleske, Nemačke, Francuske, Austrije i drugih evropskih zemalja.

9 Tako se npr. u članu 9. Zakona o izboru narodnih poslanika utvrđuje, pored osta$\log$, da birač ,odlučuje o predloženim kandidatima i izbornim listama”, da birač ima pravo „da kandidatima javno postavlja pitanja”, da birač ima pravo da bude obavešten o programima i aktivnostima podnosilaca izbornih lista i o kandidatima sa liste. Dakle, zakonodavac u izbornom postupku nije napustio individualni odnos između kandidata i birača. Vid. o tome opširnije, Stenogram sa Javne rasprave u predmetu IU-197/2002, održane u Ustavnom sudu 26. februara 2003. godine. 
nu od najznačajnijih faza izbornog postupka, u kojoj stranke imaju odlučujuću ulogu, ali onog momenta kad je kandidat predložen odnosno istaknut, on postaje pretendent na javnu-državnu funkciju i stvar tada ,ulazi iz sfere političkog prostora u postupak izbora koji je pravno uređen", i gde je u krajnjem, u momentu glasanja, biračka volja odlučujuća.

Saglasno članu 42. Ustava svaki građanin koji navrši 18 godina života ima pravo da bira i da bude biran u Narodnu skupštinu, a izbori su neposredni, biračko pravo je opšte i jednako, a glasanje je tajno. Polazeći od Ustava, u Zakonu o izboru narodnih poslanika, pored punoletstva navedeni su i još neki uslovi za ostvarivanje izbornog prava (biračkog prava), kao što su: prebivalište, državljanstvo i poslovna sposobnost građanina. Članstvo u političkoj stranci odnosno koaliciji nije predviđeno kao uslov za sticanje pasivnog biračkog prava građanina, tj. prava građanina da bude biran u Narodnu skupštinu i u druge organe i izborna tela, niti je pak članstvo u političkoj stranci, odnosno koaliciji propisano kao uslov za njihovo kandidovanje, pa otuda ni prestanak tog svojstva ne može biti uslov za gubitak ostvarenog prava (poslaničkog mandata).

Ustavnopravni položaj narodnih poslanika u Narodnoj skupštini kandidovanih od strane grupe građana jednak je $\mathrm{i}$ isti kao $\mathrm{i}$ onih poslanika koji su kandidovani i birani iz reda članova političke stranke ili koalicije, kao i onih poslanika koji su izabrani na listi političke stranke a nisu članovi te niti bilo koje stranke. Međutim, osporenim odredbama člana 88 . stava 1. tačka 1) Zakona čini se ustavnopravno neutemeljeno razlikovanje položaja narodnih poslanika, kada je u pitanju prestanak njihovog mandata u zavisnosti od jedne političke činjenice, a to je članstva u političkoj stranci koja ih je kandidovala. Osporene odredbe Zakona stavljaju u nejednak položaj narodne poslanike istog parlamenta sa stanovišta prestanka mandata, u zavisnosti od toga ko ih je kandidovao, sa čije liste su izabrani i da li su ili nisu članovi političke stranke. To je po našem mišljenju suprotno i članu 13. Ustava, prema kome su građani jednaki u pravima i dužnostima i imaju jednaku zaštitu pred državnim i drugim organima bez obzira na... političko ili drugo uverenje... ili koje lično svojstvo.

Prema tome, iz iznetog proizlazi da se uslovi za ostvarivanje pasivnog biračkog prava, pa i za njegov prestanak, ne utvrđuju u procesu kandidovanja, odnosno predlaganja kandidata na listi političke stranke ili koalicije, niti ostvarivanje tog prava zagarantovanog Ustavom može zavisiti od tipa izbornog sistema. Predlaganje kandidata na izbornim listama jeste način ostvarivanja prava na kandidovanje iz člana 42. stav 3. Ustava, i samo ostvarivanje tog prava može zavisiti od vrste izbornog sistema (proporcionalni ili većinski). Iz činjenice da je politička stranka ili koalicija kandidovala građanina na svojoj izbornoj listi ne mogu se izvlačiti posebna prava i ovlašćenja političke stranke, odnosno koalicije u odnosu prema narodnom poslaniku, koja bi imala i pravni, obavezujući karakter, uključujući i pravo stranke na oduzimanje mandata. Kako članstvo u političkoj stranci, odnosno drugom obliku povezivanja stranaka nije ustavni uslov za sticanje pasivnog biračkog prava, odnosno nije uslov za kandidovanje, 
niti uslov za izbor na funkciju narodnog poslanika, zakonsko utvrđivanje prestanka članstva u političkoj stranci, ili koaliciji kao osnova za prestanak poslaničkog mandata, odnosno gubitak ostvarenog pasivnog biračkog prava, nije u skladu sa čl. 13. i 42. Ustava.

Članom 76. Ustava predviđeno je da narodni poslanik predstavlja građane izborne jedinice u kojoj je izabran, dok je članom 2. stav 2. Ustava utvrđeno da građani ostvaruju suverenost, pored ostalog, i preko „svojih slobodno izabranih predstavnika”. Kako je prema članu 4. Zakona o izboru narodnih poslanika Republika Srbija jedna izborna jedinica, to danas narodni poslanik u Narodnoj skupštini predstavlja sve građane Republike Srbije. Navedena načela utvrđena u odredbama čl. 2. i 76. Ustava, kao i odredba člana 74. stav 2. Ustava, po kojoj se narodni poslanici biraju na neposrednim izborima, su temeljna načela, odnosno odredbe koje određuju odnos birača i narodnih poslanika i prirodu poslaničkog mandata, pa otuda sve druge norme u pravnom poretku koje se odnose na mandat poslanika, uključujući i sticanje i prestanak mandata, moraju polaziti od ovih ustavnih odredbi.

U stavu 3. člana 74. Ustava ustavotvorac upućuje da će se izbor i prestanak mandata narodnih poslanika urediti zakonom. S obzirom na karakter ove odredbe, autonomija zakonodavca u uređivanju izbora i prestanka mandata narodnih poslanika opredeljena je pomenutim odredbama Ustava koje se odnose na način sticanja poslaničkog mandata i karakter tog mandata. To znači da nezavisno od načina kandidovanja i subjekata kandidovanja, kandidat prema Ustavu stiče svojstvo narodnog poslanika činom izbora od strane građana (član 74. stav 2), i od tog momenta poslanik postaje predstavnik građana (član 76 . Ustava) preko koga građani ostvaruju svoja suverena prava, saglasno članu 2. stavu 2. Ustava. Prema tome, iz navedenih odredaba Ustava ne proizlazi da pravo na kandidovanje i samo kandidovanje od strane političke stranke odnosno koalicije utvrđeno u članu 42. Ustava znači da kandidat, a kasnije narodni poslanik, predstavlja samo one koji su ga predložili, kao ni one koji su „za njega glasali", već sve građane izborne jedinice u kojoj je izabran. Dakle, narodni poslanici, kao što im i ime kaže, prema Ustavu u Narodnoj skupštini reprezentuju građane (narod) koji su im dali svoj glas, a ne samo one koji su ih kandidovali. U protivnom bi onaj koji ne odlučuje konačno o sticanju svojstva poslanika (politička stranka, odnosno koalicija) već samo predlaže kandidata imao veća ovlašćenja u odnosu na poslanika od onog koji odlučuje o samom sticanju tog svojstva (biračko telo) i koga po Ustavu poslanik predstavlja.

Savremeni ustavotvorac Republike Srbije izričito ne govori o slobodnom mandatu narodnih poslanika, ali Republika Srbija je prema Ustavu država koja počiva na načelu građanskog suvereniteta, odnosno narodnog (građanskog) predstavništva oličenog u Narodnoj skupštini i narodnim poslanicima kao predstavnicima građana u toj Skupštini. Utvrđujući u članu 76. Ustava princip po kome narodni poslanik predstavlja građane izborne jedinice, i neuslovljavajući i neograničavajući ovo predstavljanje 
nikakvim pravno obaveznim nalozima čije nepoštovanje bi imalo za posledicu prestanak mandata, i podupirući nezavisnost i samostalnost narodnog poslanika u drugim odredbama Ustava (uključujući i odredbu člana 77. Ustava o imunitetu narodnih poslanika) ustavotvorac je po našem mišljenju pošao od slobode poslanika u predstavljanju građana u Narodnoj skupštini. Osim toga, u Ustavu nema odredaba koje bi, makar i na posredan način, upućivale na mogućnost uvođenja elemenata imperativnog mandata, odnosno ograničenja poslanika u vršenju njegovog mandata. Uređivanjem prestanka mandata na način kako je to učinjeno u osporenoj odredbi Zakona, zakonodavac na posredan način menja ustavom opredeljenu prirodu poslaničkog mandata i faktički uvodi ,prikriveni” imperativni mandat poslanika, ali ne u odnosu na one koje po Ustavu poslanik predstavlja - koji su ga izabrali i koji mu jedini mogu dati svojstvo narodnog poslanika, već u odnosu na političku stranku odnosno koaliciju na čijoj je listi kandidovan za narodnog poslanika. Međutim, polazeći od člana 2. stav 2. i čl. 74. i 76. Ustava, smatramo da zakonodavac nije mogao uvoditi kvazi opoziv, odnosno da se zakonom mandat poslanika ne može učiniti neposredno zavisnim od članstva u političkoj stranci, odnosno koaliciji na čijoj listi je kandidovan za narodnog poslanika, a što je učinjeno osporenom odredbom člana 88. stav 1. tačka 1) Zakona o izboru narodnih poslanika.

Narodni poslanik vrši javnu funkciju u Narodnoj skupštini Republike Srbije, kao državnom organu, pa prema tome, prestanak mandata poslanika - kao javne funkcije koja se vrši u skladu s Ustavom i propisima, ne može biti samo stvar političke stranke, odnosno stvar unutrašnjih (internih) odnosa političke stranke i njenog člana koji je istovremeno i narodni poslanik. Narodni poslanik, kao nosilac javne funkcije u državnom organu, kao što je Narodna skupština, ima Ustavom zagarantovanu slobodu u predstavljanju onih koji su ga birali i ne može biti vezan pravno obavezujućim nalozima političkih partija odnosno koalicija, čije bi nepoštovanje moglo imati za posledicu prestanak mandata. ${ }^{10} \mathrm{Iz}$ prava na kandidovanje i isticanje kandidata na izbornoj listi ne može se, po našem mišljenju, zakonom ustanovljavati pravna odgovornost narodnih poslanika u odnosu na subjekt koji ga je kandidovao. Naime, narodni poslanik kome je prestalo članstvo u političkoj stranci, odnosno koaliciji sa čije je liste izabran, može imati političku i moralnu obavezu da vrati mandat, odnosno podnese ostavku ali pravna obaveza nije Ustavom konstituisana.

Preko garantovanja i zaštite mandata narodnih poslanika štiti se u prvom redu ustavni položaj i uloga Narodne skupštine kao ustavotvornog

10 Ukoliko politička stranka nije zadovoljna radom njenog člana - narodnog poslanika sa stanovišta zastupanja njenih stavova u Narodnoj skupštini, politička stranka ima pravo da takvog poslanika isključi iz svog članstva (što je stvar partijske discipline), kao i što poslanik može da istupi iz članstva stranke koja ga je kandidovala, ali prestanak članstva ne bi moglo da ima za neposrednu posledicu prestanak mandata narodnog poslanika. U krajnjem, ,najteža posledica prestanka članstva u političkoj stranci za narodnog poslanika nastupiće tek po isteku mandata", jer ga ta stranka neće više kandidovati za narodnog poslanika. 
i zakonodavnog organa vlasti, a potom i ostvareno biračko pravo građanina. Narodni poslanik jeste nosilac javne funkcije koja se za period od četiri godine ostvaruje u Narodnoj skupštini, u skladu s Ustavom. Odredba člana 88. stav 1. tačka 1) Zakona čini zavisnim trajanje poslaničkog mandata od postojanja jednog političkog odnosa, tj. članstva u političkoj stranci ili koaliciji, a time i od jednog ličnog svojstva poslanika kao što je političko uverenje, što, po našem mišljenju, nije u skladu sa odredbama čl. 13. i 44. Ustava, koje jamče slobodu političkih delovanja, kao ni sa članom 74. stav 2. i članom 76. Ustava. " Takođe, predviđajući prestanak mandata narodnog poslanika zbog prestanka članstva u političkoj stranci, odnosno koaliciji osporenim odredbama Zakona, narušava se i ustavno načelo utvrđeno u članu 2. stav 2. prema kome građani ostvaruju suverenost i preko ,svojih slobodno izabranih predstavnika”.

S obzirom na izloženo, smatramo da osporena odredba člana 88. stav 1. tačka 1) Zakona nije u skladu sa čl. 2, 13, 42. i 44, članom 74. stav 2. i članom 76. Ustava. Osnove i način prestanka mandata narodnog poslanika pre isteka vremena na koje je biran, zakonodavac mora, na osnovu ovlašćenja iz člana 74. stav 3. Ustava, urediti tako da vodi računa o Ustavom zagarantovanoj suverenosti građana i načinu njenog ostvarivanja, ustavnim slobodama i pravima, kao i ustavnom opredeljenju mesta $i$ uloge Narodne skupštine i da utvrđujući osnove za prestanak mandata narodnih poslanika ne povredi Ustavom zagarantovanu prirodu poslaničkog mandata odnosno prirodu političkog predstavljanja utvrđenu u pomenutim odredbama Ustava. Pravo isticanja, odnosno predlaganja kandidata utvrđeno u članu 42. stav 3. Ustava ne znači da kandidat reprezentuje samo građane koji su ga kandidovali pošto postoji u Ustavu izričito pravilo o tome koga predstavlja poslanik.

U pogledu osporene odredbe člana 88. stav 1. tačka 9) Zakona, prema kojoj narodnom poslaniku prestaje mandat pre isteka vremena na koji je izabran brisanjem iz registra kod nadležnog organa političke stranke, odnosno druge političke organizacije na čijoj listi je izabran, ${ }^{12}$ pored iznetog ukazujemo i na sledeće:

Narodni poslanik dobija mandat, u smislu člana 74. stav 2. Ustava, od građana na neposrednim izborima. Bez obzira da li su kandidati predloženi na uninominalnim ili proporcionalnim izborima, da li ih predlaže na osnovu člana 42. stav 3. Ustava, politička stranka ili koalicija, druga politička organizacija ili grupa građana, svojstvo poslanika se stiče isključivo činom izbora. Dakle, svojstvo poslanika se može steći jedino voljom biračkog tela. S obzirom na to da ne postoji ustavnopravno utemeljena

11 Naime, biračko telo činom izbora i brojem glasova, u krajnjem, opredeljuje da li će kandidat za poslanika uopšte steći svojstvo poslanika, a ta odluka je van domašaja subjekta kandidovanja - političke stranke, odnosno koalicije ili grupe građana.

$12 \mathrm{U}$ vezi sa osporenim odredbama člana 88. Zakona ukazujemo na određenu zakonodavnu nedoslednost ispoljenu u ovim odredbama, jer zakonodavac u tački 1) govori o ,političkoj stranci ili koaliciji” a u tački 9) o ,političkoj stranci, odnosno drugoj političkoj organizaciji”. 
veza između birača i poslanika u toku trajanja mandata u smislu pravne vezanosti u ostvarivanju funkcije narodnog poslanika (član 76. Ustava), pa ni u pogledu prestanka mandata, tada se „sudbina mandata” narodnog poslanika zakonom ne može neposredno vezati za statusne i organizacione promene političke stranke, odnosno druge političke organizacije koja ih je kandidovala za narodnog poslanika.

Takođe, osporena odredba člana 88. stav 1. tačka 9) Zakona nije u skladu ni sa odredbom člana 44. Ustava kojom se jamči sloboda političkog organizovanja i delovanja, s obzirom da ta odredba svojom sadržinom i posledicama koje može izazvati (prestanak mandata narodnog poslanika), po našem mišljenju, ograničava ostvarivanje ustavne slobode promene oblika političkog organizovanja i delovanja, pa i onog oblika do koga dolazi samom voljom političke stranke i njenih članova.

Osporena odredba Zakona nije u saglasnosti sa članom 13. Ustava, jer se njome takođe povređuje ustavni princip o jednakosti građana. Ustavno ovlašćenje zakonodavca da uredi prestanak mandata narodnog poslanika, podrazumeva uređivanje opšteg režima prestanka mandata koji jednako važi za sve narodne poslanike, nezavisno od njihovih ličnih svojstava.

Iz svega iznetog proizlazi da zakonodavac ne može, kroz utvrđivanje osnova za prestanak mandata, kako je to predviđeno u osporenim odredbama člana 88. stav 1. tač. 1) i 9) Zakona, rešavati problem očuvanja partijske discipline, niti pitanje održavanja stranke u političkom i pravnom životu između dva izborna ciklusa, a da time ne povredi ustavne odredbe koje opredeljuju karakter mandata narodnih poslanika (član 2. stav 2, član 74. stav 2 i član 76), kao i odredbe o političkim slobodama i pravima građana (čl. 13, 42. i 44. Ustava).

Stečeno svojstvo narodnog poslanika na neposrednim izborima je perfektuirana pravna situacija, čije trajanje po Ustavu ne može biti uslovljeno promenom političkog uverenja, odnosno političke orijentacije, kako na strani poslanika, tako ni na strani političke stranke. Političkim strankama ne mogu se zakonom dati ovlašćenja koja će imati za posledicu promenu sastava Narodne skupštine kao zakonodavnog organa, kao što ni politički ili pravni život stranke sa čije je liste određeni poslanik izabran, prema Ustavu, ne može nakon izbora, imati neposredni uticaj na sastav Narodne skupštine.

\section{VII}

U sagledavanju ustavne zasnovanosti odredaba Zakona o izboru narodnih poslanika koje se odnose na prestanak mandata narodnih poslanika, konstatovali smo da su u Ustavu izostale bitne odredbe koje bi jasnije opredelile mandat narodnog poslanika (kao što su odredbe o opredeljivanju i glasanju poslanika po sopstvenom uverenju, izričito proklamovanje slobodnog mandata i njegove nepovredivosti, o ustavno sudskoj zaštiti iz- 
bornog prava i dr.). Isto tako, u Zakonu o izboru narodnih poslanika postoje određene pravne praznine i nedograđenosti, kao i međusobne neusaglašenosti pojedinih rešenja, koja se pre svega odnose na način ostvarivanja Ustavom zagarantovnog izbornog prava i ustavne odredbe po kojoj se narodni poslanici biraju na neposrednim izborima, a posebno u onom delu Zakona koji reguliše postupak kandidovanja, utvrđivanje izbornih lista, tip izbornih lista, način raspodele mandata, pravnu zaštitu izbornog prava, uključujući i pravnu zaštitu ostvarenog pasivnog biračkog prava, postupak odlučivanja o razlozima za prestanak mandata, itd. Takođe, postoji i određena neusklađenost pojedinih rešenja u Zakonu sa međunarodnim standardima utvrđenim u oblasti izbornog prava (kao što su npr. dokumenti KEBS-a iz Kopenhagena i dr.). Pored navedenog, mišljenja smo da je neophodno preispitati i pojedine odredbe Poslovnika Narodne skupštine koje se odnose na ostvarivanje prava i dužnosti narodnih poslanika, potom odredbe koje se tiču obrazovanja, uloge i rada poslaničkih grupa, kao i odredbe koje se odnose na način konstatovanja prestanka mandata narodnih poslanika. Dosadašnja praksa i broj sporova pred nadležnim organima, pa i ovim sudom, zbog povrede Ustavom zajamčenog izbornog prava, potvrđuje da je ovo oblast koja zahteva potpuniju i precizniju ustavnu uređenost, a posebno adekvatniju zakonodavnu i poslovničku razradu, jer je normativna uređenost izbornog prava bitna pretpostavka ostvarivanja političkih sloboda i prava građana i razvoja demokratskog parlamentarnog predstavništva.

Otuda predlažemo da Ustavni sud po odlučivanju u ovom predmetu, kao i drugim predmetima vezanim za ostvarivanje izbornog prava koji se nalaze pred ovim sudom uputi pismo Narodnoj skupštini i ukaže na probleme u ostvarivanju ustavnosti i zakonitosti u ovoj veoma značajnoj oblasti građanskih sloboda i prava. 